\title{
Kısmi Yük Koşullarında Dizel-Biyogaz Kullanılarak Çift Yakıtlı Dizel Motorun Enerji ve Ekserji Analizi
}

\author{
M. Rasit Atelge ${ }^{1 *}$ \\ 1* Siirt Üniversitesi, Mühendislik Fakültesi, Makine Bölümü, Siirt, Türkiye, (ORCID: 0000-0002-0613-2501), rasitatelge@gmail.com
}

(İlk Geliş Tarihi 3 Temmuz 2021 ve Kabul Tarihi 9 Eylül 2021)

(DOI: $10.31590 /$ ejosat.961833)

ATIF/REFERENCE: Atelge, M.R., (2021). Kısmi Yük Koşullarında Dizel-Biyogaz Kullanılarak Çift Yakıtlı Dizel Motorun Enerji ve Ekserji Analizi. Avrupa Bilim ve Teknoloji Dergisi, (27), 334-346.

\section{$\ddot{O} \mathbf{z}$}

Artan enerji talebi ve bunu doğrultusunda aşıı fosil yakıt kullanımı dünyamızı olumsuz şekilde etkilemektedir. Alternatif yakıt kaynaklarından biyogaz, araçlar için de potansiyel bir alternatif yakıt olarak tanımlanmaktadır. Bu çalışma, deneysel olarak çift yakıtlı motor sisteminde $0,000125 \mathrm{kilogram} / \mathrm{saniye}$ debiyle simüle edilmiş biyogaz kullanılarak $1500 \mathrm{rpm}$ sabit hızda, \%25, \%50 ve $\% 75$ kısmi motor yüklerinde direk enjeksiyonlu dizel motorun enerji ve ekserji analizlerini kapsamaktadır. Deney sonuçları, kısmi yükün artmasıyla enerji ve ekserji verimliği hem sadece dizel yakıt için hem de dizel-biyogaz yakıtı için artma eğilimi göstermiş̧ir. Elde edilen faydalı iş her iki yakıt türü içinde $\% 25, \% 50$ ve $\% 75$ kısmi yüklemelerinde sırasıyla $1,60 \mathrm{~kW}, 3,20 \mathrm{~kW}$ ve $4,81 \mathrm{~kW}$ olarak belirlenmiştir. Dizel yakıt için, kısmi yüklemelere göre kayıp güç miktarı $\% 25$ yük için $5,18 \mathrm{~kW}, \% 50$ yük için $7,99 \mathrm{~kW}$ ve $\% 75$ yükleme koşulunda $11,32 \mathrm{~kW}$ olarak hesaplanmıştır. Bu kayıplar, çift yakıtlı modda \%25 yükleme için 8,04 kW, \%50 yükleme oranında $9,91 \mathrm{~kW}$ ve $\% 75$ yüklemede ise $12,36 \mathrm{~kW}$ olarak elde edilmiştir. Kayıplardaki bu artış, biyogaz içerisinde bulunan \%30 CO2'nin bulunması silindir içerisindeki oksijen konsantrasyonunu azaltmakta ve tam yanmanın gerçekleşememesiyle açıklanmıştır. Sadece dizel kullanılarak yapılan deneylerde sistemin enerji verimi $\% 25, \% 50$ ve $\% 75$ yüklemeler için sırasıyla $\% 25,75, \% 29,40$ ve $\% 29,64$ olarak bulunurken çift yakıtlı sistemde biyogaz eklenmesiyle enerji veriminde sırasıyla \%18,01, \%25,27, \%27,97 olarak belirlenmiştir. Ekserji verimliliği ise dizel yakıtı kullanıldığında aynı yükleme koşulları için sırasıyla \%22,96, \%26,21 ve \%26,43 olarak hesaplanırken, çift yakıtlı sistemde bu değerler \%17,17, \%23,59 ve \%25,80 olarak bulunmuştur.

Anahtar Kelimeler: Çift Yakıtlı Dizel Motor, Enerji ve Ekserji Analizi, Biyogaz, Biyoyakıt.

\section{Energy and Exergy Analyses of Dual Fuel Diesel Engine Using Diesel- Biogas at Partially Load Conditions}

\begin{abstract}
Increasing energy demand and excessive use of fossil fuels negatively affect our world. Biogas is defined as a potential alternative fuel for vehicles. This study covered energy and exergy analyses of the direct injection diesel engine at $1500 \mathrm{rpm}$ constant speed $25 \%$, $50 \%$ and $75 \%$ partially load condition using simulated biogas with a flow rate of 0.000125 kilograms/second with a dual fuel engine system. Results revealed that energy and exergy efficiency tended to increase both for diesel fuel and diesel-biogas fuel with the increase of partial load. The obtained work was $1.60 \mathrm{~kW}, 3.20 \mathrm{~kW}$ and $4.81 \mathrm{~kW}$ for $25 \%, 50 \%$ and $75 \%$ loading condition for both fuel types. For diesel fuel, the amount of lost power was calculated as $5.18 \mathrm{~kW}$ for $25 \%$ load, $7.99 \mathrm{~kW}$ for $50 \%$ load and $11.32 \mathrm{~kW}$ with $75 \%$ loading condition. These losses were obtained as $8.04 \mathrm{~kW}$ for $25 \%$ loading, $9.91 \mathrm{~kW}$ at $50 \%$ loading rate and $12.36 \mathrm{~kW}$ on $75 \%$ loading in dual fuel mode. This increase in losses was explained by the presence of $30 \% \mathrm{CO} 2$ in biogas, reducing the oxygen concentration in the cylinder and preventing combustion process. For diesel fuel, the energy efficiency of the system was $25.75 \%$, $29.40 \%$ and $29.64 \%$ for loadings of $25 \%, 50 \%$ and $75 \%$ respectively, while the energy efficiency was determined as $18.01 \%, 25.27 \%$, $27.97 \%$ with the addition of biogas in the dual fuel system. Exergy efficiency was calculated as $22.96 \%, 26.21 \%$ and $26.43 \%$ respectively for the same loading conditions when diesel fuel was used, while in the dual fuel system these values were found to be $17.17 \%, 23.59 \%$ and $25.80 \%$.
\end{abstract}

Keywords: Dual Fuel Diesel Engine, Energy and Exergy Analysis, Biogas, Biofuel.

* Sorumlu Yazar: rasitatelge@gmail.com 


\section{Giriş}

Fosil yakıtların olumsuz etkilerinin belirlenmesiyle birlikte yenilenebilir enerji teknolojilerinin geliştirilmesi ve yaygınlaştırılması uluslararası önem kazanmıştır. Bu noktada, fosil yakıtların yerine alternatif yenilenebilir yakıtların kullanılmasıyla taşıma sektöründe daha çevreci ve sürdürülebilir kalkınmaya önemli bir katkı sağlanabilir. Bu bağlamda, biyogaz, merkezi olmayan enerji üretim uygulamaları için olduğu kadar araçlar için de potansiyel bir alternatif yakıt olarak tanımlanmaktadır (Atelge, 2021; Börjesson ve ark., 2008; Subramanian ve ark., 2013). Biyogaz, kendiliğinden tutuşma sıcaklığının yüksek olması nedeniyle dizel motorlarında dizel yakıtın yerine tamamen kullanılamaz; fakat, bu motorların ihtiyacı olan enerjinin bir kısmı biyogaz ile sağlanabilir (Goga ve ark., 2020; Subramanian ve ark., 2013). Literatürde, elektrik üretimi için biyogaz - dizel çift yakıtlı motorun performansı ile uzun vadeli dayanıklılı̆̆ı incelenmiş ve 2000 saat biyogaz beslemeli motor test ile dizelin kütleye göre \%90'nın biyogaz ile karşılanabileceğinin mümkün olduğunu, motor bozulmasına dair önemli bir işaret bulunmadığı rapor edilmiştir (Tippayawong ve ark., 2007). Biyogaz birçok avantaja sahip olmasına rağmen, kullanımı yavaş üretim oranı, aşındırıcı maddeler, düşük kalorifik değer ve temizlik gereksinimleri gibi birçok teknik zorlukla da karşı karşıyadır.

Anaerobik parçalama işlemiyle elde edilen biyogazın ana birleşenleri olarak metan (CH4) (\%60-75) ve karbondioksitten (CO2) (\%20-35) oluşurken, içerisinde azot (N2) ve hidrojen sülfit $(\mathrm{H} 2 \mathrm{~S})$, hidrojen $(\mathrm{H} 2)$ ve su $(\mathrm{H} 2 \mathrm{O})$ gibi az miktarda diğer gazlarda bulunmaktadır. Miktar olarak çok düşük oranlarda olmasına rağmen, H2S ve su buharı biyogazın kullanıldığı cihazlarda aşındırıcı etkiler göstermiş ve temizlenmesi için birçok teknoloji geliştirilmiştir (Atelge ve ark., 2021; Atelge ve ark., 2020). Bu olumsuz etkiye sahip bileşenlerin dışında, ham biyogazda CO2'nin varlığı gazın kalorifik değerini ve alev hızını azaltarak motorların termal verimliliğinin azalmasına neden olmaktadır (Bari, 1996; Barik ve ark., 2014; Bora ve ark., 2016; Duc ve ark., 2007). Ayrica, CO2'nin biyogazdan temizlenmesi maliyeti yüksek bir işlemdir ve önemli miktarda enerji gerektirir. $\mathrm{Bu}$ nedenle literatürde, biyogaz içerisindeki $\mathrm{CH} 4$ ve $\mathrm{CO} 2$ 'nin yüzdesel oranlarındaki değişikliklerinin dizel motor performansı üzerine etkileri incelenmiştir (Henham ve ark., 1998). Biyogaz içerisindeki $\mathrm{CO} 2$ yüzdesinin artması, CO emisyonlarındaki önemli artışla birlikte genel verimlilikte düşüşe neden olduğu bulunmuştur. Ayrıca, egzoz gazı sıcaklığı ve CO emisyonları üzerinde ise motora biyogazın besleme debisinin, biyogazın içerisindeki CO2 yüzdesinden daha etkili olduğu bulunmuştur. Başka bir çalışmada, simüle edilmiş biyogaz kullanarak çift yak1tlı motorun performansı üzerindeki $\mathrm{CH} 4$ ve $\mathrm{CO} 2$ 'nin yüzdesel orandaki değişiminin etkisi incelemiş ve biyogaz içerisinde \%20-30'a kadar CO2'nin bulunması, motorun tam yük altında performansını iyileştirdiği ve bunun frene özgü yakıt tüketiminin azaldığı rapor edilmiştir (Bari, 1996). Ancak, CO2 bu belirtilen aralıktan fazla olması motor performansı üzerindeki olumlu etkinin azalmasına neden olduğu bildirilmiştir. $\mathrm{Bu}$ artışın nedeni ise yanma sirasında $\mathrm{CO} 2, \mathrm{CO}$ ve $\mathrm{O} 2$ birleşenlerine ayrıldığı ve bununda yanmayı olumlu etkilediğiyle açıklanmıştır. Öte yandan, biyogaz içerisinde $\mathrm{CO} 2$ konsantrasyonun yüksek olduğun durumlarda CO2'nin bir miktar bileşenlerine ayrılmadan kaldığ 1 ve bu kalan kısmın, silindir içindeki yakıt karışımının yanma hızını azaltan seyreltici olarak davrandığı rapor edilmiştir. Yine çift yakıtlı benzinli bir motor ile yapılan yanma analizi deneylerinde, biyogaz içerisindeki $\mathrm{CO} 2$ yüzdesinin \%40'a yükseltildiğinde, fren termal verimliliğinin $\% 3$ oranında azaldığı ve HC emisyonlarının artığı bildirilmiştir (Huang ve ark., 1998). Matuszewska ve ark. (2016) tarafindan yapılan çalışmada ise biyogazın dizel motorlarda kullanımı daha düşük partikül madde (PM) ve azot oksit (NOx) emisyonları ve daha yüksek karbon monoksit (CO) ve hidrokarbon (HC) emisyonlarına sebep olduğu bildirilmiştir, ancak biyogazdaki CO2 konsantrasyonları \%30 ila \%40 arasında olması önemli bir değiş̧ikliğe sebep olmadığı gözlenmiştir.

Biyogazla ilgili $\mathrm{CO} 2$ yüzdelerinin etkisinin araştırılması dışında literatürde dizel motorlarda sıkıştırma oranlarının ve yakıt püskürtme zamanın üzerine yapılmış çalışmalar da mevcuttur. Biyogaz çift yakıtlı motorların performansını artırmak için ağırlıklı olarak önceden karıştırılmış şarj sıkıştırma ateşleme yanma modunu denemişler ve daha homojen karışım oluşumuna ve dolayısıyla daha iyi yanma verimliliğine izin veren erken dizel enjeksiyonu (piston üst ölü noktadan 55-70。 önce) ile elde edildiği bildirilmiştir (Mohamed Ibrahim ve ark., 2015). Biyodizel - biyogaz çift yakıtlı dizel motorların kırsal alanlarda enerji üretme seçeneği olarak kullanılmasının fizibilitesi araştırılmıştır. Bora ve ark. (2016), bir dizel motorda 17 - 18 arasında değişen sıkıştırma oranlarında biyodizelbiyogaz çift yakıtlı sistemde deneyler gerçekleştirmişler ve yüksek sıkıştırma oranlarında çift yakıtlı çalışmanın hem performans hem de emisyonlarda iyileşme gözlendiğini bildirmişlerdir. Saf Jatropha yağı ve biyogaz kullanılarak çift yakıt modunda deneysel bir araştırma yapılmış ve çift yakıtlı sistemin daha yüksek yüklerde termal verimliliğin dizel yakıt kullanılarak yapılan deney sonuçlarıyla karşılaştırılabilir olduğu, ancak düşük yükte eksik yanmadan dolayı termal verimlilikte \%10'luk bir düşüşe sebep olduğu bildirilmiştir (Luijten ve ark., 2011). Barik ve ark (2014) direk enjeksiyonlu dizel motorda biyogaz üretimi ve kullanımına odaklanan kapsamlı bir çalışma yapmışlar ve küspe ve hayvan gübresi ile \%73 $\mathrm{CH} 4$ konsantrasyonu sahip biyogaz üretimini gerçekleştirmişlerdir. Üretilen bu biyogaz, çift yakıtlı dizel motorda $0,3-1,2 \mathrm{~kg} / \mathrm{saat}$ farklı besleme debileriyle yanma testlerini yapmışlardır. 100\% motor yükünde, dizel yakıta kıyasla NOx ve duman emisyonlarında sirasıyla $\% 39$ ve $\% 49$ azalma tespit edilirken, $\mathrm{CO}$ ve $\mathrm{HC}$ emisyonlarında sırasıyla $\% 17$ ve $\% 30$ artış ile termal verimlilikte \%6,2 düşüş olduğu tespit edilmiştir (Barik ve Murugan, 2014).

Biyogaz çift yakıtlı motorun performans değerlendirmesi üzerinde şimdiye kadar yapılan çalışmaların çoğu enerji analizine dayanmaktadır ve doğası gereği belirli kayıp kaynaklarını ve göreceli büyüklüklerini belirleme yeteneğinden yoksundur. Termodinamiğin ikinci yasasına dayanan ekserji analizi, içten yanmalı motor performanslarını, çeşitli süreçlerde meydana gelen tersinmezliklerin ve bunların büyüklüklerinin karşılaştırarak analiz etmek ile birlikte daha doğru sonuçlar elde edilebilir. Ancak literatürde biyogaz çift yakıtlı motorların ekserji değerlendirmesine odaklanan çok az çalışma vardır. Sorathia ve ark. (2012) dizel ve dizel-biyogaz yakıtlı kullanarak $\% 100$ motor yükünde karşılaştırmalarını enerji ve ekserji analizini yaparak ortaya koymuşlardır. Sonuçlarına göre çift yakıtlı sistemde biyogaz ilavesinin tam yükte motor performansına herhangi bir olumsuz etki yapmadı sonucuna ulaşmışlardır. Diğer bir çalışmada, dizel-biyogaz çift yakıtlı motorun sıkıştırma oranındaki ve dizel yakıt enjeksiyon zamanlamasındaki değişimlerin termodinamik analiz ile enerji ve ekserji üzerindeki etkilerini incelemişlerdir (Bora Bhaskor ve ark., 2016). Tam yükte gerçekleştirilen tüm testler için, 
sıkıştırma oranındaki artışın ve enjeksiyon zamanlamasının motorun çift yakıt çalışması için ekserji performansını artırdığı bulunmuştur. Sıkıştırma oranın 18 ve enjeksiyon zamanlamasında piston üst ölü noktadan $29^{\circ}$ olduğunda, en yüksek ekserji verimliliği ve daha düşük egzoz gazı ekserjisi elde edildiğini rapor etmişlerdir.

Mevcut literatürdeki sunulan bilgileri dayanarak, biyogaz kullanılarak çift yakıtlı motor sisteminin motorun kısmi ve tam yüklerde motor performansına ve emisyon sonuçlarına etkileri araştırılmıştır. Bu etkileri tahmin etmek ve nedenlerini anlamak için şimdiye kadar yapılan çalışmalar genelde enerji analizine dayanmaktadır. Ekserji analizleri ile ilgili raporlar ise motorun tam yük koşulu altında yapılmış çalışmalardır. Kısmi yüklerde, enerji ve ekserji analizlerine dayanan bir çalışma, örneğin kayıplara neden olan çeşitli tersinmezlikleri tanımlamak ve karşılaştırmak biyogazın biyoyakıt olarak kullanılması için daha faydalı bilgiler sağlayabilir. Bu tür araştırmalar, yakıt seçiminde ve ayrica biyogaz çift yakıtlı motor teknolojisinin geliştirilmesine yardımcı olabilir. Bu çalışma, literatürdeki bu eksikliği gidermeye katkı sağlamak için, çift yakıtlı motor sisteminde $0,000125 \mathrm{kilogram} / \mathrm{saniye}$ debiyle simüle edilmiş biyogaz kullanılarak, $\% 25, \% 50$ ve $\% 75$ kısmi motor yüklerinde bir direk enjeksiyonlu dizel motorun enerji ve ekserji analizlerini kapsamaktadır. Çıkan sonuçlar, motorun bu çalışma koşullarında dizel kullanılarak elde edilen sonuçlarıyla kıyaslanarak meydana gelen farkların sebepleri enerji ve ekserji analizleriyle ele alınmıştır.

\section{Materyal ve Metot}

\subsection{Kullanılan Yakıtların Özellikleri}

$\mathrm{Bu}$ çalışma için simüle edilen biyogazın içerisindeki gaz karışım oranları önceki çalışmamızdan elde edilmiştir. Önceki çalışmamızda, biyogaz üretimi için besi kaynağ 1 olarak yağ çıkarılmış kahve telvesi kullanılmıştır (Atelge ve ark., 2021). Üretilen biyogazdaki $\mathrm{CH} 4$ ve $\mathrm{CO} 2$ yüzdeleri gaz kromatografisi analizi (Shimadzu GC-2010 Plus) ile belirlenmiştir. Test sonuçları, gram uçucu katı başına $336 \pm 7 \mathrm{~mL} \mathrm{CH} 4$ üretildiği belirlenmiş ve üretilen biyogazın hacimsel olarak \%70,05'ini $\mathrm{CH} 4, \% 28,75$ 'ini $\mathrm{CO} 2$ ve geri kalan1 ise eser gazlardan oluştuğunu ortaya koymuştur (Atelge ve ark., 2021). Bu nedenle, bu deneyde biyogazı simüle etmek için hacimsel olarak $\% 70$ $\mathrm{CH} 4$ ve \%30 $\mathrm{CO} 2$ karıştırılarak dizel motorun emme manifoldundan verilmiştir. Barik ve ark. (2014) tek silindirli bir dizel motorda biyogazın debisi üzerine çalışma yapmışlar ve sonuçları en yüksek BTE'nin $0,3 \mathrm{~kg} / \mathrm{saat}$ biyogaz akış hızından elde edildiğini ortaya koymuşlardır. Deneylerinde kullandıkları test motoru tek silindirli ve hacmi $662 \mathrm{~cm} 3$ olduğundan, bu deneysel çalışmada kullanılan test motorunun silindir hacmine orantılanarak simüle edilmiş biyogazın debisi $0,000125 \mathrm{~kg} / \mathrm{s}^{\prime} l \mathrm{lk}$ olarak seçilmiştir. Bu karışımı elde etmek için saflıkları sırasıyla $\% 99,999$ ve \%98,9 olan $\mathrm{CH} 4$ ve $\mathrm{CO} 2$ gazları kullanılmıştır. Simüle edilmiş biyogaz içerisindeki hacimsel yüzdelerini belirlemek ve deney süresince sabit tutmak için iki akış ölçer (Alicat, M100 SLPM) kullanılmıştır. Tablo 1'de biyogazın özellikleri sunulmuştur.

Tablo 1 Biyogaz yakıt özellikleri

\begin{tabular}{l|c|c}
\hline & Değerler & Kaynak \\
\hline Alt 1sı değeri (MJ/kg) & 20,84 & $*$ \\
\hline $\begin{array}{l}\text { Yoğunluk (kg/m³) (1 atm ve } \\
288 \mathrm{~K})\end{array}$ & 1,2 & $\begin{array}{c}\text { (Barik ve ark., } \\
\text { 2016) }\end{array}$ \\
\hline Alev yayılma hızı (m/s) & 25 & $\begin{array}{c}\text { (Barik ve } \\
\text { Murugan, 2016) }\end{array}$ \\
\hline Oktan sayıs1 & 130 & $\begin{array}{c}\text { (Barik ve } \\
\text { Murugan, 2014) }\end{array}$ \\
\hline Parlama noktası (K) & 1087 & $\begin{array}{c}\text { (Bora ve ark., } \\
\text { 2014) }\end{array}$ \\
\hline Stokiyometrik hava yakıt oran & 10 & $\begin{array}{c}\text { (Bora ve ark., } \\
\text { 2014) }\end{array}$ \\
\hline
\end{tabular}

* $\mathrm{CH}_{4}$ oranına göre hesaplanmıştır

Kullanılan dizel yakıt OPET akaryakıt istasyonundan euro dizel olarak temin edilmiştir. Bu yakıt ile ilgili yüklenici firmadan temin edilen veriler Tablo 2'de sunulmuştur.

Tablo 2 Euro dizel yakıt özellikleri

\begin{tabular}{l|c}
\hline & Değerler \\
\hline Alt 1sı değeri (MJ/kg) & 42,65 \\
\hline Yoğunluk $\left(\mathrm{kg} / \mathrm{m}^{3}\right)(1 \mathrm{~atm}$ ve $288 \mathrm{~K})$ & 840,5 \\
\hline Setan sayıs1 & 51 \\
\hline Parlama noktası $(\mathrm{K})$ & 328 \\
\hline Stokiyometrik hava yakıt oran & 14,46 \\
\hline Kimyasal bileşim (kütlesel) & $\mathrm{C}_{12} \mathrm{H}_{23}$ \\
\hline H/C & 0,1597 \\
\hline O/C & 0 \\
\hline S/C & $\sim 0$ \\
\hline Euro dizelin ekserji faktörü & 1,0744 \\
\hline
\end{tabular}

\section{2. Çift Yakıtlı Dizel Motor Test Sistemi}

Yanma ve emisyon testleri için dört zamanlı, üç silindirli, su soğutmalı, doğrudan enjeksiyonlu dizel motorda gerçekleştirilmiştir. Çift yakıt modunu ayarlamak için, motorun emme manifolduna, gaz besleme için bir hortum bağlanarak modifiye edilmiştir. Bu çalışmada biyogaz ve dizel sırasıyla birincil yakıt ve pivot yakıt olarak kullanılmıştır. Deney için kullanılan motor test sistemi şematik olarak Şekil 1'de sunulmuştur. Deneyler, test edilen tüm yakıtlar ve yükler için $1500 \mathrm{rpm}$ sabit motor hızında gerçekleştirilmiş̧ir. Motoru yüklemek için, tork kapasitesi 0 ve $450 \mathrm{Nm}$ aralı̆ğında olan Net Fren-NF150 marka hidrolik dinamometre, dizel motor mili ile birleştirilmiştir. Motor yükünü belirlemek için kapasitesi $0,1 \mathrm{~g}$ hassasiyetle $200 \mathrm{~kg}$ olan bir yük sensörü (CAS, SBA 200L) kullanılmıştır. Motor performansları $\% 25, \% 50$ ve $\% 75$ kısmi motor yüklerinde dizel yakıt ve dizel-biyogaz çift yakıt modunda gerçekleştirilmiştir. 


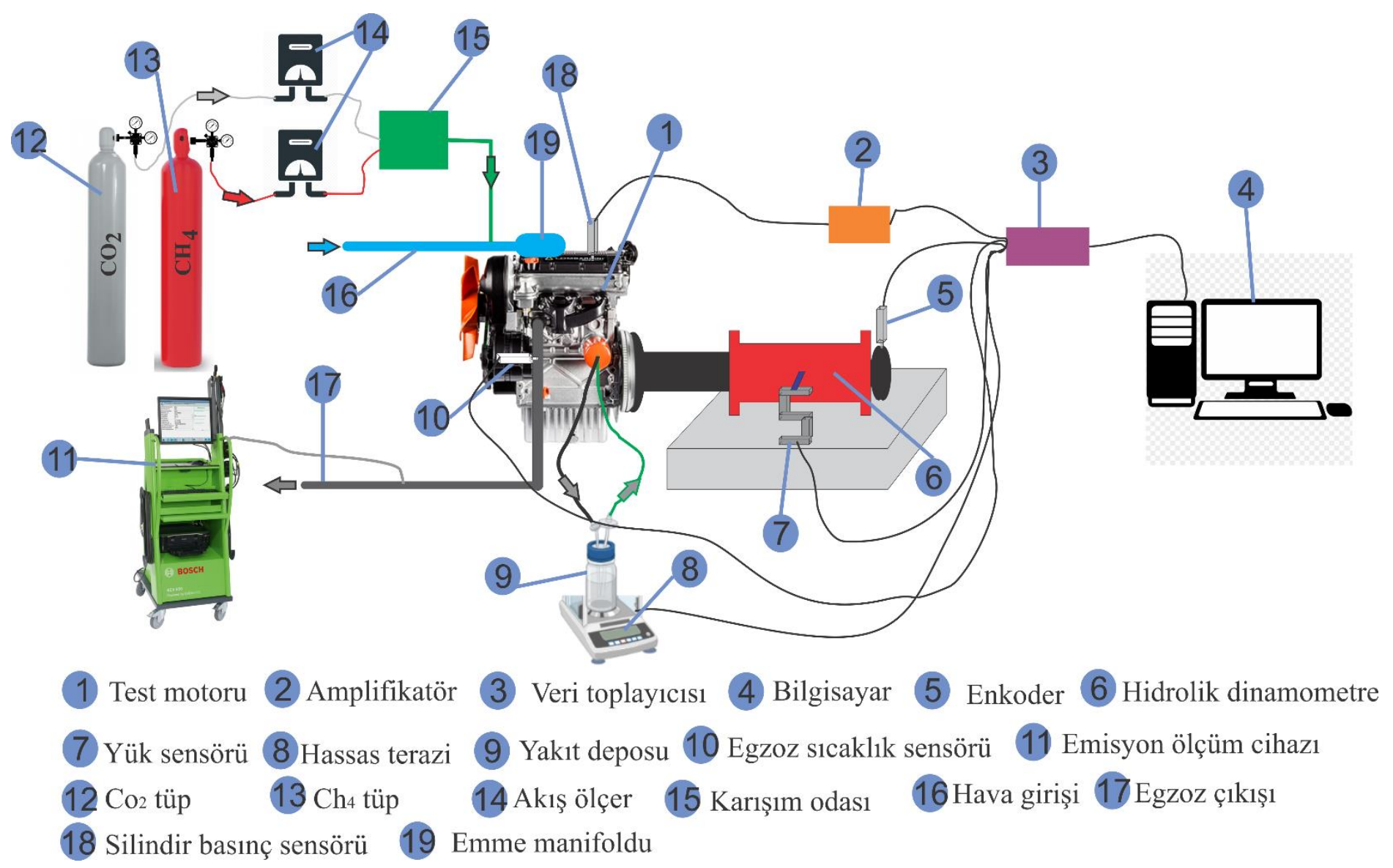

Şekil 1 Çift Yakutlı Dizel Motor Test Sisteminin Şematik Gösterimi

\subsection{Termodinamik Analizi}

Termodinamiğin ilk yasası enerjinin korunmasına dayanır ve enerjinin yaratılamayacağını veya yok edilemeyeceğini vurgular. $\mathrm{Bu}$ nedenle sistemdeki enerji giriş ve çıkışlarını belirlemek için birinci kanun analizi yapılmaktadır (Kiliç ve ark.). Bu kanun, endüstriyel tesislerdeki tüm enerji tüketen cihazlar için geçerlidir ve sistemdeki tersinmezliklerden kaynaklanan kayıpları dikkate almaz. Termodinamiğin ikinci yasası, sistemlerin gerçek enerji potansiyelini anlamak için entropi oluşturmayı ve iş yapma yeteneğini analiz eder. Tersinebilir sistemler dışında, ekserji enerji gibi korunmaz; ekserjinin bir kısmı sistemdeki tersinmezliği nedeniyle yok edilir ve bir kısmı sistem sınırının etrafından atılır (Karaağaç ve ark., 2019; Yildiz ve ark., 2020).

Motor enerjisi ve ekserji analizleri, yanma reaksiyon denklemlerinden elde edilen yanma ürünleriyle hesaplanır. $\mathrm{Bu}$ doğrultuda çift yakıtlı yanma için literatürde verilen formda test yakıtının yanma reaksiyon denklemine göre hesaplanmıştır (Denklem (1)) (Verma ve ark., 2017).

\begin{tabular}{rl|}
$C_{a} H_{b}+y\left(m C H_{4}\right.$ & $\left.+n C O_{2}\right)+z\left(O_{2}+3,76 N_{2}\right)$ \\
& $\rightarrow w\left(\alpha C O_{2}+\beta C O+\gamma N O+\delta O_{2}\right)$ \\
& $+v N_{2}+q \mathrm{HO}_{2}$
\end{tabular}

$\mathrm{Bu} \quad$ denklemde $\alpha, \beta, \gamma$ ve $\delta$ egzoz gazı türlerinin katsayılarıdır ve egzoz gazı analizinden elde edilmiştir.
Denklemin bilinmeyen y, z, w, v ve q karbon, hidrojen, oksijen ve azot dengesi yapılarak elde edilmiştir.

Motor enerjisi ve ekserji analizleri için aşağıdaki kabuller yapılmıştır;

- Motorun sabit durumda çalıştı̆̆1,

- Hava, hava-yakıt karışımı ve egzoz gazlarının ideal gaz davranışına sahip olduğu,

- Giren ve çıkan kütlelerle ilişkili kinetik ve potansiyel enerjiler ihmal edilebilir olduğu,

- Referans basinci $\left(\mathrm{P}_{0}\right)$ ve sicaklık $\left(\mathrm{T}_{0}\right)$ sirasiyla 1 $\operatorname{atm}(101,325 \mathrm{kPa})$ ve $21^{\circ} \mathrm{C}(294,15 \mathrm{~K})$ olduğu,

- Motorun genel performansı için, tüm motor sistemi kontrol hacmi olarak alındığı, silindir içi analiz için sadece silindir kontrol hacmi olarak seçildiği,

- Egzoz gazı emisyonlarındaki küçük miktarlar nedeniyle hesaplamalarda $\mathrm{HC}$ ve yanmamış yakıtların ihmal edilebilir olduğu,

kabul edilmiştir (Kumar Sharma ve ark., 2020; Verma ve ark., 2018). 


\subsubsection{Enerji Analizi}

Enerji sisteme yakıt şeklinde sağlanır. Bu enerji, şaft iş çıkışı, soğutma için atmosfere 1sı transferi, egzoz gazları tarafından taşınan enerji vb. Termodinamiklerin ilk yasasının öngördüğü gibi, mevcut motor sistemi için enerji dengesi denklemi şu şekilde yazılabilir (Verma ve ark., 2017; Yildiz ve Çalişkan, 2020):

\begin{tabular}{|c|c|}
\hline$\sum \dot{E}_{g}=\sum \dot{E}_{\varsigma}$ & (2) \\
\hline$\dot{E}_{g}=\dot{E}_{y}+\dot{E}_{h}$ & (3) \\
\hline$\dot{E}_{\mathrm{c}}=\dot{E}_{i \varsigma}+\dot{E}_{e}+\dot{E}_{k}$ & (4) \\
\hline
\end{tabular}

Denklem (2)'de $\dot{E}_{g}$ toplam giren enerjiyi, $\dot{E}_{c ̧}$ toplam çıkan enerji temsil etmek üzere, Denklem (3)'de $\dot{E}_{y}$ sisteme giren yakıtın toplam kimyasal enerjisini ve $\dot{E}_{h}$ ise sisteme giren havanın enerjisini temsil etmektedir. Denklem (4)'te ise $\dot{E}_{i \S}$ üretilen net gücü, $\dot{E}_{e}$ egzoz gazlarının enerjisini (Jadhao ve ark., 2013) ve $\dot{E}_{k}$ ise sistemde meydana gelen enerji kayıpların ifade etmektedir. $\dot{E}_{y}$ ve $\dot{E}_{h}$ Denklem (5) ve (6)'ya göre, $\dot{E}_{i \S}, \dot{E}_{e}$ ve $\dot{E}_{k}$ ise Denklem (7), (8) ve (9)'a göre hesaplanmıştır (Kumar Sharma ve ark., 2020; Verma ve ark., 2017; Yildiz ve Çalişkan, 2020).

\begin{tabular}{|c|c|}
\hline$\dot{E}_{y}=\left(\dot{m}_{D} \times H_{D}\right)+\left(\dot{m}_{B G} \times H_{B G}\right)$ & (5) \\
\hline$\dot{E}_{h}=\left(\dot{m}_{h} \times h_{h}\right)$ & (6) \\
\hline$\dot{E}_{i \varsigma}=\frac{2 \times \pi \times n \times T}{60}$ & (7) \\
\hline$\dot{E}_{e}=\left(\dot{m}_{D}+\dot{m}_{B G}\right) \times(1+H Y O) \times\left(c_{p_{e}}\right) \times\left(T_{e}-\right.$ & (8) \\
$\left.T_{0}\right)$ & \\
\hline$\dot{E}_{k}=\dot{E}_{y}+\dot{E}_{h}-\dot{E}_{i \varsigma}-\dot{E}_{e}$ & (9) \\
\hline
\end{tabular}

Denklem (4)'den motora sağlanan yakıt giriş enerjisini $\left(\dot{E}_{y}\right)$, $\dot{m}_{D}$ ve $\dot{m}_{B G}$ sirasiyla dizel ve biyogaz yakıt kütlesel debisi, $H_{D}$ ve $H_{B G}$ yakitların alt 1 sil değerlerini ifade etmek üzere birbirleriyle çarpımlarının toplanmasıyla elde edilmektedir. Yanma havasında gelen enerji değeri $\left(\dot{E}_{h}\right)$ Denklem (5)'e göre hesaplanır. Sistemden elde edilen efektif güç $\left(\dot{E}_{i s}\right)$ Denklem (6)'ya göre hesaplanır. Denklem (6)'da n devir sayısını (devir/dakika), $\mathrm{T}$ motor torkunu ifade etmektedir. Denklem (7)'den ise egzoz enerjisini $\left(\dot{E}_{e}\right)$, giren yakıtların hava fazlalık katsayısı (HYO), egzoz gazı özgül ısı ve referans sıcaklığı ile egzoz gazı sıcaklıklarının çarpımı ile belirlenir. Sistemin enerji kaybı ise Denklem (8)'e göre hesaplanır.

Sistemin termal verimliliği termodinamiğin birinci yasasına göre Denklem (10)'da verildiği üzere hesaplanır.

$$
\eta_{I}=\frac{\dot{E}_{i \Im}}{\dot{E}_{y}} \times 100
$$

\subsubsection{Ekserji Analizi}

Ekserji dengesi, çeşitli motor proseslerinde enerji dağılımının nitel bir hesabını verir. Enerji ve ekserji dengeleri arasındaki temel fark, birincisinin enerjinin korunması yasasına, ikincisi ise enerjinin bozulması yasasına dayanmasıdır. Mevcut içten yanmalı motor sisteminin ekserji analizi dengesi aşağıdaki gibi yazılabilir (Verma ve ark., 2017; Yildiz ve Çalişkan, 2020):

$$
\sum \dot{X}_{g}=\sum \dot{X}_{c}+\sum \dot{X}_{y l k l m}
$$

Denklem (11)'de giren ve çıkanları dikkate alındığında aşağıdaki şekilde ifade edilebilir.

$$
\dot{X}_{y}+\dot{X}_{h}=\dot{X}_{i \varsigma}+\dot{X}_{e}+\dot{X}_{k}+\dot{X}_{\text {ylkm }}
$$

Denklem (12)'de $\dot{X}_{y}, \dot{X}_{h}, \dot{X}_{i s ̧}, \dot{X}_{e}, \dot{X}_{k}$ ve $\dot{X}_{\text {ylkım siyasiyla }}$ yakıtın, havanın, güç, egzoz, kayıp ve yıkım ekserjileri ifade etmektedir ve aşağıdaki denklemlere göre hesaplanır (Kumar

\begin{tabular}{|c|c|}
\hline$\dot{X}_{y}=\dot{X}_{D}+\dot{X}_{B G}$ & (13) \\
\hline $\begin{aligned} \dot{X}_{D}=\dot{m}_{D} \times H_{D} & \times\left\{1,0401+0,178 \times\left(\frac{H}{C}\right)+0,043\right. \\
& \times\left(\frac{O}{C}\right)+0,2169 \times\left(\frac{S}{C}\right) \\
& \left.\times\left(1-2,0628\left(\frac{H}{C}\right)\right)\right\}\end{aligned}$ & (14) \\
\hline$\dot{X}_{B G}=\dot{m}_{B G} \times\left(\sum_{i} x_{i} e_{i_{0}}+T_{0} \sum_{i} x_{i} R \ln \left(x_{i}\right)\right)$ & (15) \\
\hline$\dot{X}_{h}=\dot{m}_{h} \times c_{p_{h, g}} \times\left[\left(T_{h, g}-T_{0}\right)-T_{0} \ln \left(\frac{T_{h, g}}{T_{0}}\right)\right]$ & (16) \\
\hline$\dot{X}_{i s ̧}=\dot{E}_{i s ̧}$ & (17) \\
\hline $\begin{array}{c}\dot{X}_{e}=\sum_{i} \dot{m}_{i} \times\left\{c_{p, i} \times\left[\left(T_{e}-T_{0}\right)-T_{0} \ln \left(\frac{T_{e}}{T_{0}}\right)\right]\right. \\
\left.+R T_{0} \ln \left(\frac{y_{i}}{y_{\text {çevre }, i}}\right)\right\}\end{array}$ & (18) \\
\hline$\dot{X}_{k}=\dot{E}_{k} \times\left(1-\frac{T_{0}}{T_{s u}}\right)$ & (19) \\
\hline$\dot{X}_{\mathrm{ylklm}}=\dot{X}_{y}+\dot{X}_{h}-\dot{X}_{i \S}-\dot{X}_{e}-\dot{X}_{k}$ & (20) \\
\hline
\end{tabular}
Sharma ve ark., 2020; Verma ve ark., 2017; Yildiz ve Çalişkan, 2020):

Denklem (13)'de $\dot{X}_{y}, \dot{X}_{D}$ ve $\dot{X}_{B G}$ motora sağlanan yakıt giriş ekserjisini toplamı olarak ifade edilmiştir. Denklem (14)'de $\dot{m}_{D}$ ve $H_{D}$ sırasıyla dizel yakıtın kütlesel debisini ve alt ssıl değerini ifade etmektedir. Geri kalan ifade ise yakıtın ekserji faktörü olarak bilinmektedir ve yakıt içerisindeki H, O, S'nin kütlesel olarak C'ye oranları ile bulunur. Denklem (15)'te biyogazdan gelen kimyasal ekserjisi biyogazın ideal gazların bir karışımı 
olduğu varsayılarak hesaplanır. Denklemde, $\dot{m}_{B G}$ biyogazın kütlesel debisini, $x_{i}$ i gazının mol oranını, $e_{i_{0}}$ i gazının standart kimyasal ekserjisini, $\mathrm{T}_{0}$ referans sicaklığ 1 ve $\mathrm{R}$ ise genel gaz sabitini ifade etmektedir. Denklem (16)'da $\dot{X}_{h}$ havanın ekserjisini ifade etmektedir. $\dot{m}_{h}, c_{p_{h, g}}$ ve $T_{h, g}$ sirasiyla havanın kütlesel debisini, sisteme giren havanın özgül ısı kapasitesini ve havanın giriş sıcaklığını ifade etmektedir. Denklem (17)'de $\dot{X}_{i s ̦}$ sistemden elde edilen faydalı işin ekserjisini ifade eder ve bu direk olarak faydalı işe eşittir. Denklem (18)'de $\dot{X}_{e}$ egzoz gazının ekserjisini, $y_{i}$ ve $y_{\text {çevre, } i}$ i gazının egzoz gazı içerisindeki yüzdesini ve çevredeki oranını belirtmektedir. Denklem (19)'da $\dot{X}_{k}$ sistemin ekserji kayılarını, $T_{s u}$ ise motor soğutma suyunun sıcaklığını ifade etmektedir. $\dot{X}_{\text {yıkım }}$ sistemin ekserji yıkımını ifade etmektedir ve Denklem (20)'ye göre hesaplanmaktadır.

Sistemin ekserji verimliliği termodinamiğin ikinci yasasına göre Denklem (21)'de verildiği üzere hesaplanır.

$$
\eta_{I I}=\frac{\dot{X}_{i s}}{\dot{X}_{y}} \times 100
$$

Tablo 3 'te çalışmada kullanılan tüm cihazların hassasiyetleri verilmiştir. Sonuçlar deneysel ölçümlerle temsil edildiğinde, cihazlar doğrulukları nedeniyle ölçümlerde belirsizliklere neden olurlar ve bu belirsizlikler sistemdeki değişkenlerin birleşiminden dolayı deney sisteminin belirsizliğini etkilerler. $\mathrm{Bu}$ nedenle, her cihazın belirsizliği, deney sisteminin belirsizliğine katkıda bulunmaktadır. Sistemin belirsizliğini hesaplamak için Eşitlik (22)'e göre yayılma belirsizliği yaklaşımı kullanılmıştır (Çakmak ve ark., 2017). Denklemde $U_{Y}$ sistemin genel belirsizliğini ifade ederken, Y $x i$ 'ye bağlı parametreyi, $U_{x i}$ ise $x i$ 'nin belirsizliğini ifade etmek üzere,

$$
\frac{U_{Y}}{Y}=\left[\sum_{i=1}^{n}\left(\frac{1}{Y} \frac{\partial Y}{\partial x i} U_{x i}\right)^{2}\right]^{\frac{1}{2}}
$$

şeklinde hesaplanır. Denkleme göre yapılan belirsizlik analizinde deney sisteminin toplam belirsizliği $\pm \% 2,25$ olarak belirlenmiştir. Buda deney sisteminin mühendislik yaklaşımlarınındı kabul edilebilir olan hata payının (\%5) altında olduğunu göstermektedir.

\subsection{Belirsizlik Analizi}

Tablo 3 Performans ve emisyon ölçümlerinde kullanılan cihazların hassasiyetleri ve belirsizlikleri

\begin{tabular}{l|l|l|l}
\hline Kullanılan Cihazlar & Hassasiyetleri & Elde edilen veriler & Belirsizlik (\%) \\
\hline Hidrolik dinamometre & $\pm 0,03 \%$ & Tork & 0,748 \\
\hline Basınç sensoru & $\pm 1 \%$ & Güç & 0,457 \\
\hline $\begin{array}{l}\text { Krank açısını belirlemek için } \\
\text { enkoder }\end{array}$ & $\pm 0,01 \mathrm{rpm}$ & BTE & 0,578 \\
\hline Silindir basıncı & $\pm 1 \%$ & BSFC & 1,125 \\
\hline CO için gaz analizörü & $\pm 0,001 \%$ & EGT & 1,078 \\
\hline HC için gaz analizörü & $\pm 1 \mathrm{ppm}$ & CO emisyonu & 0,375 \\
\hline NO için gaz analizörü & $\pm 1 \mathrm{ppm}$ & HC emisyonu & 0,298 \\
\hline Hassas terazi & $\pm 0,1 \%$ & NO emisyonu & 0,586 \\
\hline K tipi termokupl & $\pm 1 \% \mathrm{C}$ & Gaz akış ölçer & $\mathbf{2 , 2 5 1}$ \\
\hline Gaz akış ölçer & $\pm 0,8 \%$ & Deney Sistemi & \\
\hline
\end{tabular}

\section{Araştırma Sonuçları ve Tartışma}

Bu çalışmadan elde edilen sonuçlar, çift yakıtlı dizel motora $0,000125 \mathrm{~kg} / \mathrm{s}^{\prime} \mathrm{l} \mathrm{k}$ biyogaz beslemesinin k1smi motor yüklerindeki enerji ve ekserji analizi olarak sunulmuştur. Tablo 3 'te enerji ve ekserji analizi gerçekleştirilen yanma testinin, motorun $\% 25, \% 50$ ve $\% 75$ k1smi yüklere göre gücünü, yakıt tüketimini, giriş havasının kütlesel debisini ve soğutma suyu sıcaklığını göstermektedir. 
Tablo 4. Yanma Deneyinde Motor Kısmi Yüklerine Göre Elde Edilen Deneysel Veriler

\begin{tabular}{|c|c|c|c|c|c|c|}
\hline Yakit & $\begin{array}{c}\text { Motor yükleme } \\
\text { oranı } \\
(\%)\end{array}$ & $\begin{array}{l}\text { Güç } \\
(\mathrm{kW})\end{array}$ & $\begin{array}{l}\text { Hava debisi } \\
\quad(\mathrm{kg} / \mathrm{s})\end{array}$ & $\begin{array}{c}\text { Dizel yakit } \\
\text { debisi } \\
(\mathrm{kg} / \mathrm{s})\end{array}$ & $\begin{array}{c}\text { Biyogaz debisi } \\
(\mathrm{kg} / \mathrm{s})\end{array}$ & $\begin{array}{l}\text { Motor soğutma } \\
\text { suyu sicaklığ1 } \\
(\mathrm{K})\end{array}$ \\
\hline \multirow{3}{*}{ D } & $25 \%$ & 1.60 & 0.005993 & 0.000146 & 0 & 340.55 \\
\hline & $50 \%$ & 3.20 & 0.003806 & 0.000256 & 0 & 346.67 \\
\hline & $75 \%$ & 4.81 & 0.002760 & 0.000380 & 0 & 348.68 \\
\hline \multirow{3}{*}{$\begin{array}{l}0 \\
n \\
+ \\
0\end{array}$} & $25 \%$ & 1.60 & 0.006367 & 0.000153 & 0,000125 & 332.77 \\
\hline & $50 \%$ & 3.20 & 0.004014 & 0.000242 & 0,000125 & 345.83 \\
\hline & $75 \%$ & 4.81 & 0.002956 & 0.000347 & 0,000125 & 348.31 \\
\hline
\end{tabular}

\subsection{Enerji Analizi}

Şekil 2'de motorun çalıșma modunda enerji dağılımları motor yüklemelerine göre sunulmuştur. Şekil 2 - a'da sadece dizel yakıt kullanılarak gerçekleştirilen deneylerde elde edilen iş miktarı motor yükünün artırılmasıyla artmıştır. Elde edilen faydalı iş $\% 25, \% 50$ ve $\% 75 \mathrm{k}$ ısmi yüklemelerinde sırasıyla 1,60 $\mathrm{kW}, 3,20 \mathrm{~kW}$ ve 4,81 kW olarak belirlenmiştir. Elde edilen faydalı iş açısında, yük oranın artması daha iyi bir enerji dönüşümüne elde edilmesine neden olmuştur. Bunun sebebi, uygulanan yükün artmasıyla yakıt akış hızlarında bir artışa bu da daha yüksek yanma sıcaklığının üretilmesine neden olur (Goga ve ark., 2020). Bu sıcaklık artışı yanma odasına giren ürünlerin daha iyi bir oksidasyon reaksiyonu gerçekleştirmesiyle sonuçlanır. Ayrıca, yüksek sıcaklık daha yüksek Carnot çevrim verimliliğine dolayısıyla da daha yüksek faydalı enerji elde edilmesine sebep olmuştur (Verma ve ark., 2018). Isı transferi ve sürtünme nedeniyle motor soğutma suyuyla kayıp olan hesaplanan enerji, yüklemenin artmasıyla artığı tespit edilmiştir. Kısmi yüklemelere göre kayıp güç miktarı \%25 yük için 5,18 $\mathrm{kW}, \% 50$ yük için $7,99 \mathrm{~kW}$ ve $\% 75$ yükleme koşulunda 11,32 kW olarak hesaplanmıştır. Bu artışın sebebi yanma sıcaklığın yükselmesinden kaynaklandığı sonucuna varılabilir. Bu yükleme koşullarına göre kayıp enerjilerin elde edilen faydalı işe göre kıyaslaması yapıldığında motor yükünün artmasıyla bu enerjilerin birbirine oranı azalmaktadır. Yani, \%25 yükleme koşulunda kayıp olan enerjinin \%30,89'zu elde edilen faydalı ișe eşit iken \%75 yüklemede bu oran \%42,44 olmaktadır. Bu da yüklemenin artmasıyla enerji veriminin artığını göstermektedir. Yakıt olarak sadece dizel kullanıldı ğı zaman egzoz gazları enerji kayıpları incelendiğinde, motor soğutma suyundan kaynaklanan kayıplar ile aynı sonuçlara varılabilir. \%25 yükleme koşulunda $0,80 \mathrm{~kW}$ egzoz gazı enerji kaybı hesaplanırken, bu kayı \%50 yüklemede $0,84 \mathrm{~kW}$ ve $\% 75$ yüklemede $0,91 \mathrm{~kW}$ olarak elde edilmiştir.
Şekil 2 - b'de çift yakıtlı dizel motor test sitemine birincil yakıt olarak $0,000125 \mathrm{~kg} / \mathrm{s}$ biyogaz beslenmesiyle elde edilen enerji dağılımını göstermektedir. Sadece dizel yakıt kullanımında tespit edilen motora uygulanan yük ile elde edilen faydalı iş arasındaki trend, çift yakıtlı yanma modunda da tespit edilmiştir. Motor yükünün artmasıyla enerji dönüşümündeki verim artmıştır. Burada sabit oranda yüklemeler yapıldığı için elde edilen faydalı işler sadece dizel yakıt kullanılarak yapılan deneyler ile aynıdır. Fakat kayıp enerji açısında bakıldığında kayıp enerjinin dizele göre yükseldiği belirlenmiştir. Ayrıca, düşük yükte egzoz gazından meydana gelen enerji kaybı sadece dizel yakıt kullanıldığındaki sonuçlardan yüksek bulunmuştur. Bunun sebebi, biyogazın emme manifoldundan beslenmesi yanma performansını düşürecek oksijen eksikliğine sebep olması olabilir (Mustafi ve ark., 2013) (Barik ve Murugan, 2014; Karim, 2010). Dahası, biyogaz içerisinde bulunan hacimsel olarak \%30 $\mathrm{CO}_{2}$ 'nin bulunması silindir içerisindeki oksijen konsantrasyonunu azaltmakta ve yanma alev hizını düşürmektedir (Cheenkachorn ve ark., 2013; Verma ve ark., 2018). Bu sebeplerden dolayı yanma işlemi tam olarak gerçekleşemez. Dolayısıyla aynı faydalı işi elde etmek için daha fazla yakıt tüketimine ve kayıpların artmasına sebep olmaktadır. Çift yakıtlı modda kayıp enerji \%25 yükleme için 8,04 kW, \%50 yükleme oranında $9,91 \mathrm{~kW}$ ve $\% 75$ yüklemede ise $12,36 \mathrm{~kW}$ olarak elde edilmiştir. Düşük yüklerde yanmanın tam olmamasından dolayı egzoz gazlarından meydana elen kayıp dizel yakıt ile yapılan deneylere göre yüksek çıkmıştır. \%25 yüklemede $0,84 \mathrm{~kW}$ ve $\% 50$ yüklemede $0,86 \mathrm{~kW}$ olarak tespit edilmiştir. Yükleme oranın \%75 olduğunda egzoz gazlarından dolayı yakıp dizel ile karşılaştırıldığında \%2'lik bir azalma göstererek 0,90 kW olarak hesaplanmıştır. Bunun sebebi ise yüksek yüklerde yanmanın düşük yüklere göre daha iyi olduğudur (Yildiz ve Çalişkan, 2020). 


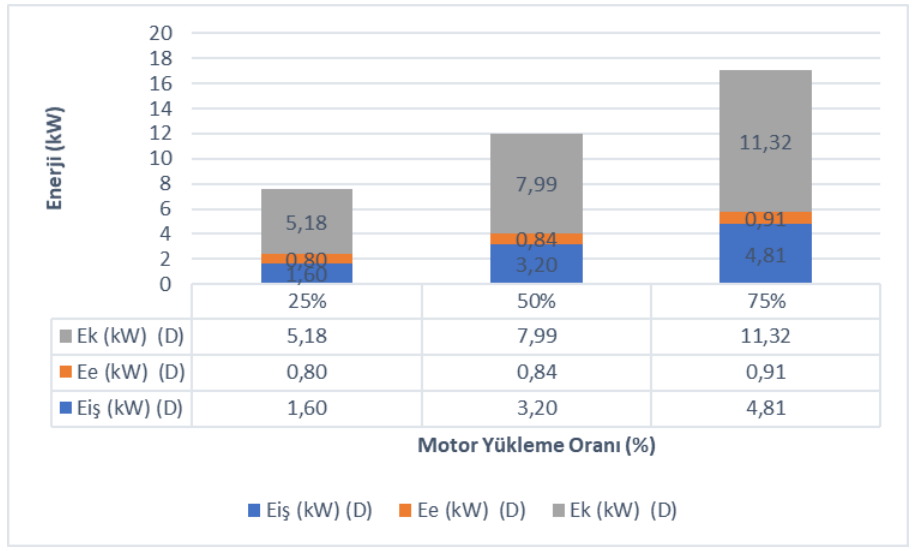

(a)

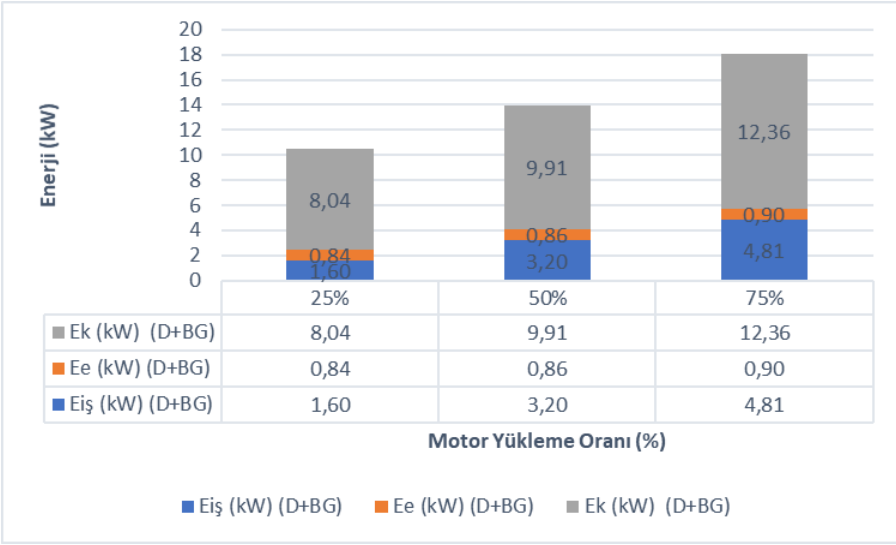

(b)

\section{Şekil 2. Dizel Motorun Sadece Dizel Yakıtla (a), Çift Yakıtla (b) Çalışmasında Enerji Dağıllımı}

Şekil 3'te giren yakıtın enerji miktarına göre yüzdesel olarak enerji dağılımları sunulmuştur. Şekil 3 - a'da sadece dizel yakıt kullanılarak yapılan deneylerde yukarıda belirtildiği gibi yükleme oranının artmasıyla elde edilen faydalı işin yüzdesel olarak artığı açıktır. Motora $\% 25$ yükleme yapıldığında $\% 25,75$ ’i faydal 1 iş olarak elde edilirken, $\% 50$ ve $\% 75$ yükleme oranlarında sırasıyla $\% 29,40$ ve $\% 29,64$ oranlarında faydalı iş elde edilmiştir. \%25 yüklemede egzoz gazı kayıpları diğer yüklemelere göre yüzdesel olarak daha fazladır. Bunun sebebi ise düşük yüklerde yanma işleminin tam gerçekleşmemesine ve giren enerji ile egzoz gazı kayıp enerjisinin arasındaki farkın küçük olmasına bağlanabilir (Yildiz ve Çalişkan, 2020). Giren yakıtın $\% 12,85, \% 7,73$ ve $\% 5,60$ egzoz kayıpları olarak sirasıyla $\% 25, \% 50$ ve $\% 75$ yükleme koşulları için hesaplanmıştır. Ayrıca, soğutma suyu ve sürtünmelerden meydana gelen kayılara bakıldığında ise en yüksek kaybın $\% 64,76$ olarak $\% 75$ motor yükleme oranında olduğu bulunmuştur. Bunun nedeni ise yanma sıcaklığının artmasından ve sıcaklık farkının yükselmesinden kaynaklı 1sı transferi ile olan kayıpların artmasından meydana gelmesidir (Goga ve ark., 2020). \%25 yükte giren yakıt enerjisine göre kayıp \%61,41 olarak hesaplanırken $\% 50$ yükleme oranında bu kayıp \%62,87 olarak belirlenmiştir.

Şekil 3 - b'de ise çift yakıt sisteminin giren yakıt enerjisine göre enerji dağılım yüzdeleri verilmiştir. Elde edilen faydalı iş dizel yakıta göre azalma eğilimi göstermiştir. Bunun sebebi alt 1sıl değeri düşük olan biyogazın kullanılmasından kaynaklanmaktadır. Elde edilen faydalı iş $\% 25, \% 50$ ve $\% 75$ yükleme koşullarında sırasıyla \%18,01, \%25,27 ve $\% 27,07$ olarak hesaplanmıştır. Egzoz gazlarında kaynaklanan kayıplar dizel yakıtta gösterdiği trendi göstererek düşük yükten yüksek yüklere doğru yüzdesel azalmıştır. Buda yükün artmasıyla yanmanın iyileştiğini göstermektedir. Çift yakıtlı sisteminde dizelden farklı olarak 1S1 transferi ve sürtünme kayıplarının egzoz gazlarına paralellik göstererek yükün artmasıyla azalmasıdır. $\% 25$ yükleme oranında hesaplanan kayıp \%72,56 iken $\% 50$ ve $\% 75$ yükleme oranlarında kayıplar siyırasıyla $\% 67,93$ ve $\% 66,79$ olarak bulunmuștur. Bunu olası nedeni ise biyogaz eklemesinin silindir içindeki oksijen oranının azalmasına ve yanmayı olumsuz etkilemesinden kaynaklanıyor olabilir (Barik ve Murugan, 2016; Verma ve ark., 2018). Ayrıca, biyogazın içerisinde bulunan $\mathrm{CO}_{2}{ }^{\prime}$ 'nin alev oluşma hızını olumsuz etkilediği literatürde rapor edilmiştir (Mustafi ve ark., 2013; Verma ve ark., 2017). Dolayısıyla giren enerjinin büyük bir kısmı tam yanmanın olmamasından kaynaklı faydalı işe dönüştürülemeden kayıp olması ile sonuçlanmaktadır. Bu olay düşük yüklerdeki düşük yanma performansıyla birleşmesi sonucu kayıp oranı düşük yükte dizelin yakıta elde edilen trendin tersi yönünde bir sonuç oluşmasına neden olmuştur. 


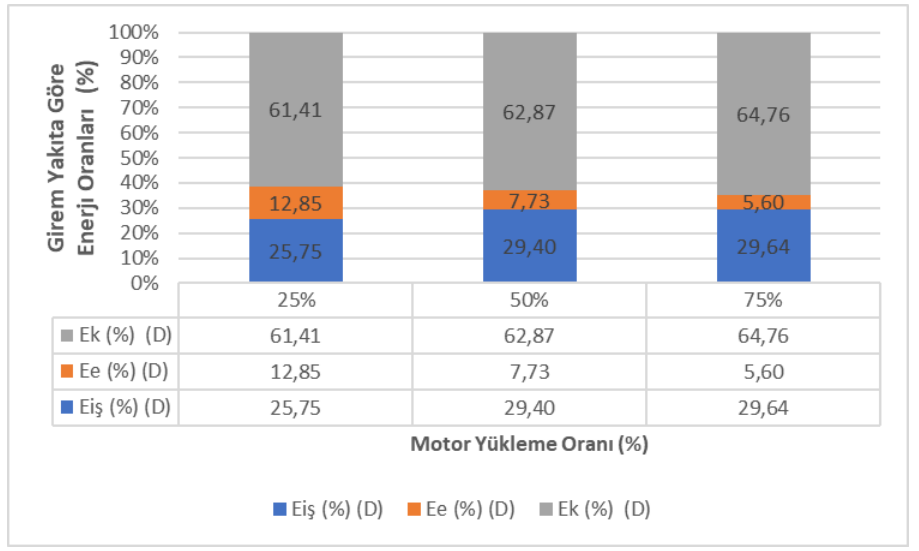

(a)

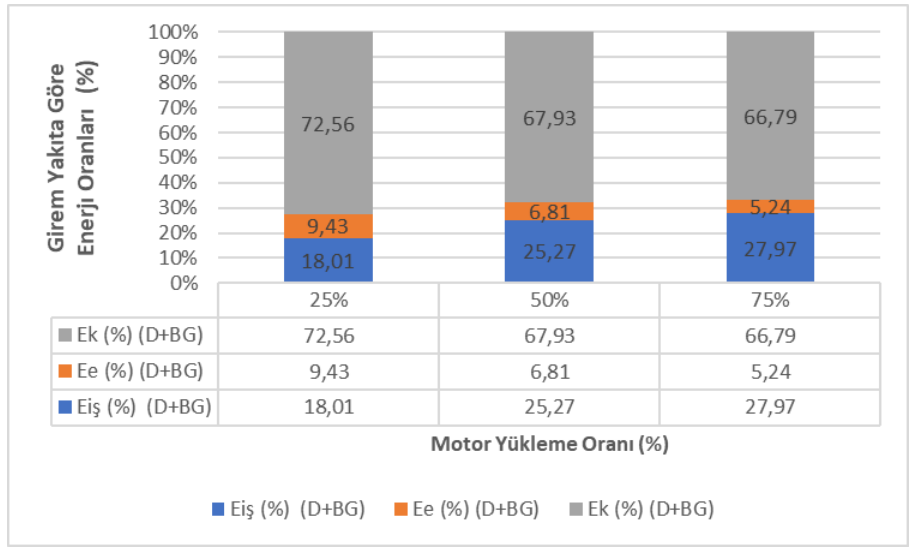

(b)

Şekil 3. Sadece Dizel (a) ve Çift Yakıt (b) Kullanımında Giren Yakıta Göre Yüzdesel Olarak Enerji Dă̆llımı

\subsection{Ekserji Analizi}

Şekil 4'de motorun tek yakıtlı veya çift yakıtlı çalışma prensibine bağlı olarak motor yüklemelerine göre ekserji dağılımı sunulmuştur. Şekil 4 - a'da sadece dizel yakıt kullanılarak gerçekleştirilen deneylerde elde edilen iş ekserjisi Denklem (17)'de ifade edildiği gibi iş enerjisine eşittir. Elde edilen faydalı iş ekserjisi $\% 25, \% 50$ ve $\% 75$ kısmı yüklemelerinde sirasıyla $1,60 \mathrm{~kW}, 3,20 \mathrm{~kW}$ ve $4,81 \mathrm{~kW}$ olarak belirlenmiş ve enerji dağılımında olduğu gibi motor yükünün artırılmasıyla artığı tespit edilmiştir. Motor sadece dizel yakıtla çalıştırıldığında egzoz ekserji kayıpları enerji analizindeki gibi motor yükünün artmasıyla artmıştır. $\% 25, \% 50$ ve $\% 75$ yüklerde egzoz ekserji kayıpları sırasıyla $0,82 \mathrm{~kW}, 0,96 \mathrm{~kW}$ ve $1,90 \mathrm{~kW}$ olarak bulunmuştur. $\mathrm{Bu}$ artış egzoz gazlarının sicaklık değerlerinin motor yüklemesiyle artmasının bir sonucudur. Soğutma suyuna transfer olan işi ekserjisi ise gene aynı yüklemelerde sırasıyla $0,71 \mathrm{~kW}, 1,21 \mathrm{~kW}$ ve $1,77 \mathrm{~kW}$ olarak hesaplanmıştır. Ekserji analizinin enerji analizinden en önemli çevreye atılan ekserji yıkımında ortaya konmasıdır. Bu yıkım sistemin tersinmezliklerinden kaynaklanmaktadır. Ekserji yıkımı sadece dizel yakitla yapılan deneylerde $3,85 \mathrm{~kW}, 6,65 \mathrm{~kW}$ ve $9,71 \mathrm{~kW}$ olarak hesaplanmıştır. Bu sonuçlar literatürde bildirilen yanmaya bağlı tersinmezliklerin önemli olduğu görülmektedir (Verma ve ark., 2017). Ekserji yıkımında meydana gelen tersinmezlikler motor yükünün artması ile azalmaktadır. Bunu sebebi ise eksik yanma ile artan tersinmezlikler motor yükünün artmasıyla azalmaktadır (Yildiz ve Çalişkan, 2020).
Şekil 4 - b'de ise çift yakıtla çalışan motor deneylerinin ekserji analizinin sonuçları verilmiştir. Ekserji analizinde egzoz kayıpları dizel motora göre \%25 yükleme için 2,6 kat, \%50 yükleme için $2,97 \mathrm{~kat}$ ve $\% 75$ yükleme için ise $1,58 \mathrm{~kat}$ daha yüksek çıkmıştır. Egzoz gazı ekserjileri sırasıyla 2,16 kW, 2,86 $\mathrm{kW}$ ve 3,00 kW olarak hesaplanmıştır. Bu farkın en önemli nedeni enerji analizinde egzoz gazları tam yanma sonucu oluşan gazlardan olduğu kabulü nedeniyle ortaya çıkmaktadır. Fakat, ekserji analizinde egzoz gazlarının birleşenleri hesaba katıldığ için ve çift yanma sisteminde $\mathrm{CO}$ egzoz gazlarında fazla olması nedeniyle egzoz kayıpları yüksek bulunmuştur. Eksik yanmanın göstergesi olan CO emisyonu yanmamış gazların entalpisinin yükseltmekte ve böylece egzoz gazı ekserjisi yüksek çıkmaktadır. Motor soğutma suyundan kaynaklana ekserji kayıpları ise $\% 25, \% 50$ ve \%75 yükler için sırasıyla $0,93 \mathrm{~kW}$, $1,53 \mathrm{~kW}$ ve $1,92 \mathrm{~kW}$ olarak belirlenmiştir. Bu değerlerde sadece dizel yakıtlı test ile karşılaştırıldığında daha yüksektir. Bu sebebi ise soğutma suyu sıcaklıkları her iki deney seti için yakın rakamlar ölçülse de ekserji kaybı, kayıp enerjinin bir fonksiyonu olduğundan çift yakıtlı sistemde daha yüksek çıkmaktadır. Yıkım ekserjisi ise 4,64 kW, $6,25 \mathrm{~kW}$ ve $8,45 \mathrm{~kW}$ olarak sirasıyla $\% 25$, $\% 50$ ve $\% 75$ yükler için hesaplanmıştır. Burada dizel yakıta göre düşük çıkmasının sebebi, egzoz ve ekserji kayıplarının daha yüksek olmasından kaynaklanmaktadır. Burada da yanma olayındaki tersinmezlikler en büyük role sahiptir (Verma ve ark., 2017). 


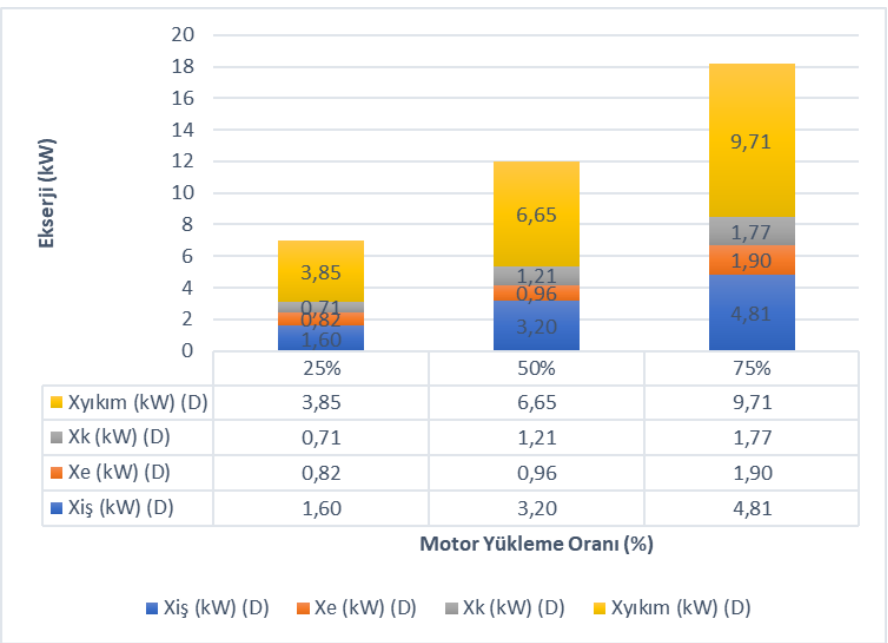

(a)

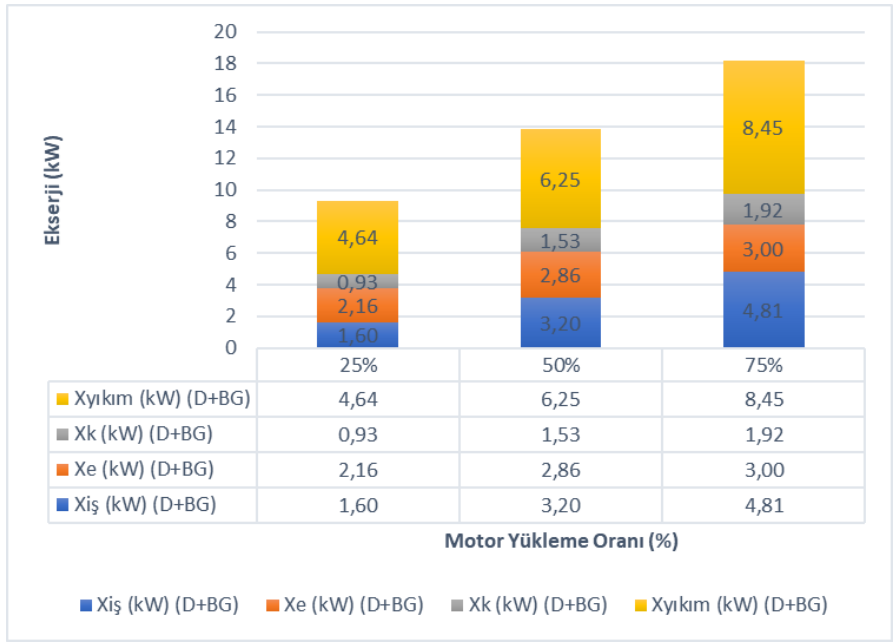

(b)

Şekil 4. Dizel Motorun Sadece Dizel Yakıtla (a), Çift Yakıtla (b) Çalışmasında Ekserji Dağıllımı

Şekil 5'te giren yakıtın enerji miktarına göre yüzdesel olarak ekserji dağılımları sunulmuş̧ur. Şekil 5 - a'da tek yakıt kullanılarak yapılan deneylerdeki giren yakıtın toplam ekserjisine göre dağılımını göstermektedir. Faydalı iş olarak elde edilen ekserjinin motor yükü artmasıyla giren yakıtın faydalı işe çevrilme oranı artmaktadır. kısmı yüklerde elde edilen faydalı iş ekserji motor yüklemelerinde küçükten büyüğe doğru sırasıyla $\% 22,96, \% 26,21$ ve $\% 26,43$ olarak bulunmuştur. Bu artış yükün artması ile daha yüksek sicaklıklara ve daha iyi bir yanma performansına ulaşmasıyla açılanabilir (Barik ve ark., 2018). Egzoz ekserji kayıpları dikkate alındığında yukarda bahsedildiği gibi ekserji değeri olarak düşük yüklerde daha düşük değer almasına rağmen yüzdesel olarak dikkate alındığında düşük yüklerde egzoz kayıp oranları daha yüksektir. $\% 25$ yüklemede egzoz kayıp ekserjisi $\% 11,70$ iken bu oran $\% 50$ yüklemelerde $\% 7,85$ 'lere kadar düşmektedir. Bu yanmanın iyileşmesinden kaynaklanmaktadır. Lakin, \%75 yükleme oranında bu değer $\% 10,42$ değerlerine çıkmaktadır. Bu artışın sebebi yükün artması ile egzoz gazı sıcaklık değerinin artmasına bağlanabilir. Soğutma suyuna 1sı transferinden dolayı geçen ekserji $\% 25, \% 50$ ve $\% 75$ yüklemeler için sırasıyla $\% 10,12, \% 7,85$ ve $\% 9,74$ olarak hesaplanmıştır. Ekserji yıkımı yukarıda bahsedildiği gibi tersinmezliklerin göstergesidir. Yanma reaksiyonlarında bu tersinmezlik yanmanın iyileşmesi yani teorik yanma noktasına yaklaşmasıyla azalır (Verma ve ark., 2019b). Şekilde görüldüğü gibi düşük yüklerde ekserji yıkımı daha fazla olduğu tespit edilmiştir. Yüksek yükleme oranlarında sıcaklık artmasına rağmen ekserji dönüşüm oranı iyileşmesinden kaynaklı ekserji yıkımı azalmaktadır. Sadece dizel yakıt kullanılarak yapılan deneylerde ekserji yıkımı $\% 25, \% 50$ ve $\% 75$ yüklemelerde sirasiyla $\% 55,23, \% 54,40$ ve $\% 53,41$ olarak bulunmuştur. Ekserji yıkımlarındaki fark içten yanmalı motorların verimine doğrudan etki etmektedir. Hesaplanan değerler, yakıt ekserjisini önemli bir kısmının yanma işleminde yok olduğunu göstermektedir. $\mathrm{Bu}$ nedenle, bir yanma işleminin tersinmezliklerin son derece büyük olduğunu göstermektedir (Verma ve ark., 2019a). Elde edilen sonuçlar aslında enerji analiziyle uyum göstermektedir, çünkü yakıtın ekserjisi yanma entalpilerinden sadece biraz farklıdır. Yanma, yakıt ve oksijenin kimyasal enerjisini yanma ürünlerinin entalpisine dönüştüren, entropi üreten ve enerji tüketen bir işlemdir (Verma ve ark., 2020). Bu işlem genellikle 1sı transferinin yanı sıra sıv1 sürtünmesi ve karıştırma ile aynı anda gerçekleşir (Verma ve ark., 2017; Verma ve ark., 2019b). Bu çalışmada bildirilen analizler hem kimyasal reaksiyon hem de 1 s1 transferini içermektedir. Bu bahsedilen olaylardan dolayı ekserji yıkımı yüzdelerinin yüksek olması beklenen bir sonuçtur.

Şekil 5 -b'de çift yakıt sisteminde giren yakıtın ekserjisine göre ekserji dağılımı yüzdesel olarak verilmektedir. Grafikte dikkat çeken nokta egzoz gazlarının ekserji kayıplarının \%15'in üzerinde olmasıdır. Çift yakıt sisteminde, biyogaz emme manifoldundan besleme yapılarak silindir içerisine verilmektedir. İçten yanmalı motorlarda egzoz gazlarının dışarı rahat atılması için emme ve egzoz subapları çok kısa süre beraber açık kalmaktadır. Bunun sonucu, silindir içerisine alınan biyogazın bir kısmı yanma reaksiyonuna katılmadan bu süre içerisinde silindiri terk ediyor olabilir (Barik ve Murugan, 2014). $\mathrm{Bu}$ da yanmamış gazların egzoz gazlarındaki yüzdelerinin artmasına sebep olur. Dolayısıyla egzoz kayıpları artmaktadır. $\% 25, \% 50$ ve $\% 75$ yükleme koşulları için egzoz kayıpları yüzdesel olarak sirasıly $\% 23,11, \% 21,03$ ve $\% 16,10$ olarak bulunmuştur. $\mathrm{Bu}$ sonuçlar, yukardaki açıklamalarla paralellik göstererek yükün artmasıyla yanmanın iyileştiğini göstermektedir. $\mathrm{Bu}$ fenomenden dolayı, çift yakıtlı sistemde egzoz ekserji kayıpları sadece dizel kullanılarak yapılan deneylere göre yaklaşık olarak $\% 25$ yüklemelerde 2 kat daha fazladır. Ekserji yıkımı ise dizel yakıta göre nispeten düşük bulunmuştur. $\% 25, \% 50$ ve $\% 75$ yükleme koşulları için ekserji yıkımı sirasiyla $\% 49,72, \% 46,02$ ve $\% 45,36$ olarak hesaplanmıştır. $\mathrm{Bu}$ azalmanın sebebi egzoz ekserjisindeki artış gösterilebilir. 


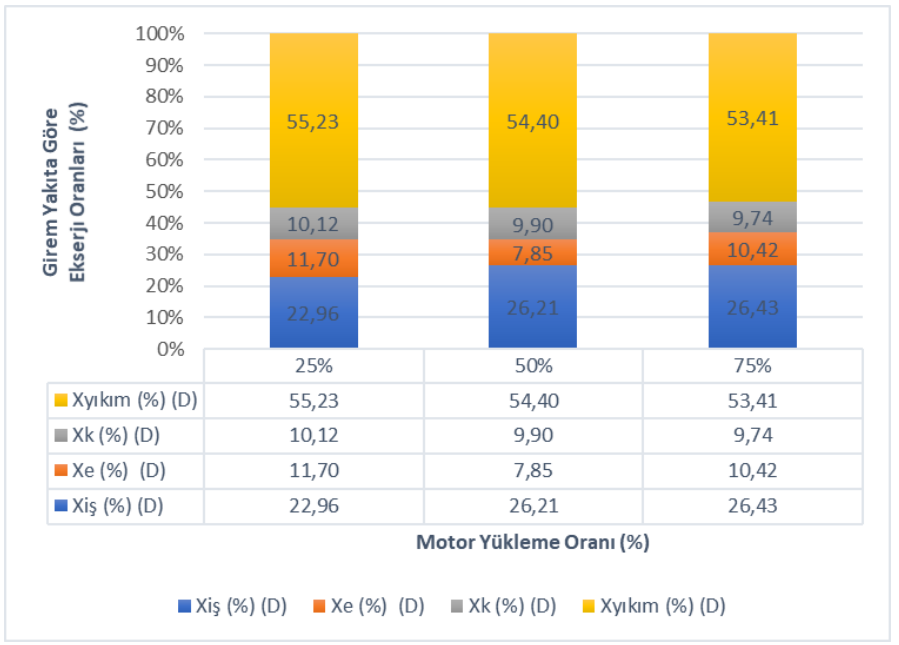

(a)

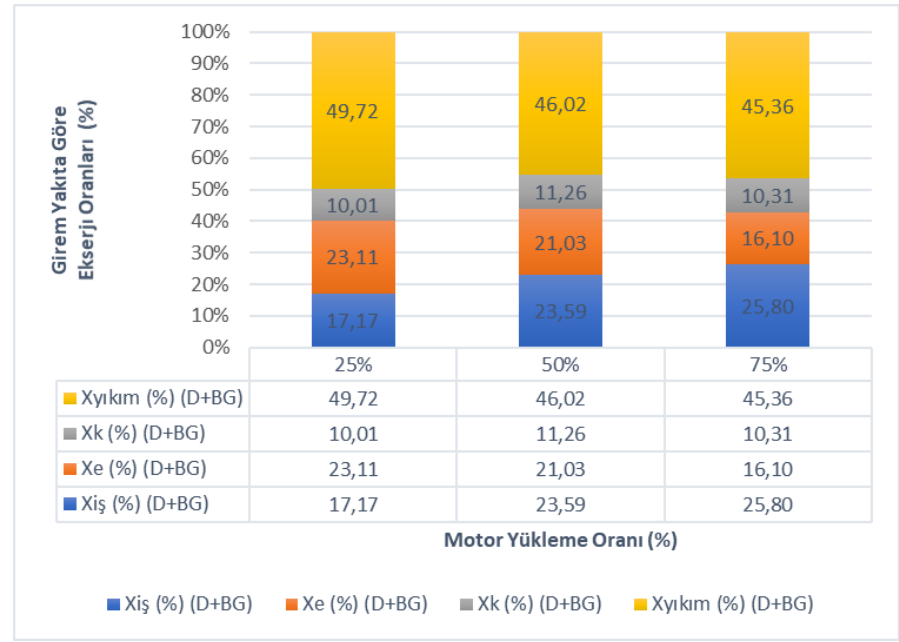

(b)

Şekil 5. Sadece Dizel (a) ve Çift Yakıt (b) Kullanımında Giren Yakıta Göre Yüzdesel Olarak Ekserji Dă̆ılımı

Şekil 6'da dizel yakıtla çalıştırılan içten yanmalı motorun ve çift yakıtlı sistem kullanılarak $0,000125 \mathrm{~kg} / \mathrm{s}^{\prime}$ lik biyogaz beslemesi yapılarak elde edilen birincil ve ikincil yasa verimleri sunulmuştur. Şekil 6 - a ve b'de açıkça görüldüğü gibi tüm test koşullarında sistemin enerji (I. Yasa verimi) ekserji veriminden daha yüksek çıkmıştır. Sadece dizel kullanılarak yapılan deneylerde sistemin enerji verimi $\% 25, \% 50$ ve $\% 75$ yüklemeler için sırasıly $\% 25,75, \% 29,40$ ve $\% 29,64$ olarak bulunmuştur. Diğer verileri destekleyecek şekilde yükün artması ile verimin artması elde edilmiştir. Bu yanma çevriminde elde edilen faydalı işin artığını göstermektedir. Fakat, çift yakıtlı sistemde biyogaz eklenmesiyle enerji veriminde düşük yükte (\%25) verim $\% 18,01$ olarak hesaplanmıştır. Bu da yanmanın en verimsiz olduğu koşul olduğunu ortaya koymaktadır. Yükün artmasıyla enerji verimi $\% 50$ için \%25,27, \%75 için \%27,97'e ulaştığı belirlenmiştir.

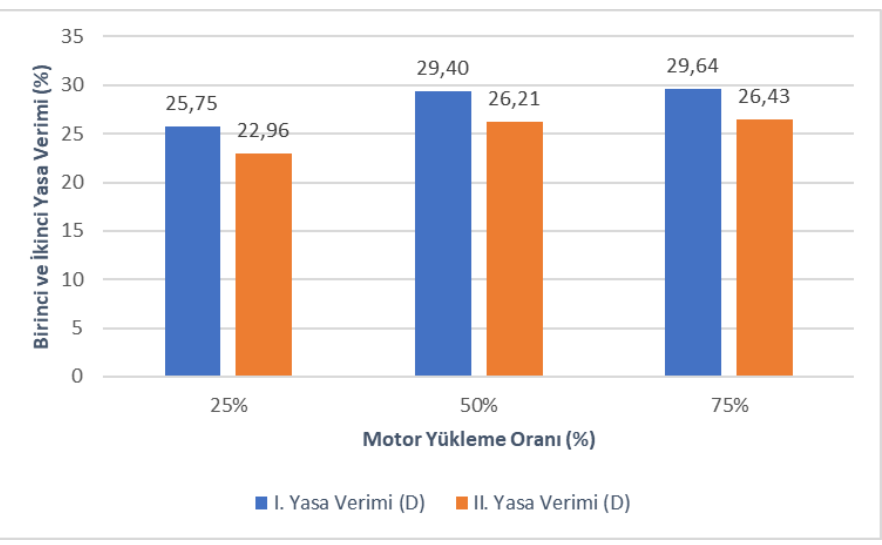

(a)
Ekserji verimlerine bakıldığında aynı trendin olduğu dikkat çekmektedir. Ekserji verimi enerji veriminden düşük çıkmıştır. $\mathrm{Bu}$ nedenle, bir yanma işleminin tersinmezliklerin son derece büyük olduğudur (Verma ve ark., 2019a; Verma ve ark., 2019b). Yanma, yakıt ve oksijenin kimyasal enerjisini yanma ürünlerinin entalpisine dönüştüren, entropi üreten ve enerji tüketen bir işlem olmasıyla açıklanabilir (Verma ve ark., 2018; Verma ve ark., 2020). Sadece dizel yakıtı kullanıldığında. $\% 25, \% 50$ ve $\% 75$ yükleme koşulları için ekserji verimliliği sırasıyla \%22,96, $\% 26,21$ ve $\% 26,43$ olarak hesaplanmıştır. Çift yakıtlı sistemde ise bu değerler $\% 17,17, \% 23,59$ ve $\% 25,80$ olarak bulunmuştur.

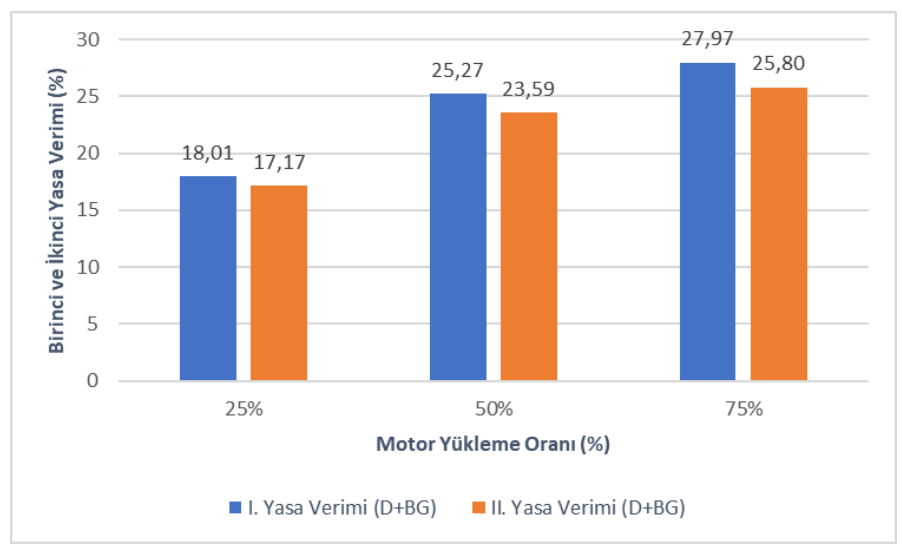

(b)

Şekil 6. Sadece Dizel (a) ve Çift Yakıt (b) Deney Düzeneğinde Enerji ve Ekserji Verimleri 


\section{Sonuç}

$\mathrm{Bu}$ çalışmada, çift yakıtlı sistemde dizel motorda biyogaz ilave edilerek motor kısmi yüklerin etkilerini incelemek için deneysel bir değerlendirme yapılmıştır. Üç kısmi yük koşulu kullanılarak, çift yakıtlı motorun performansı, birinci ve ikinci yasa analizleri yapılmış ve bu sonuçlar sadece dizel kullanılarak elde edilen veriler ile karşılaştırılmıştır. Yukarıdaki sonuçlara ve tartışmaya dayanarak, bu çalışmadan aşağıdaki sonuçlar elde edilebilir;

1. Enerji ve ekserji analizlerine göre en iyi motor performans $1 \% 75$ yük koşulunda elde edilmişstir.

2. Yükün azalması ile hem dizel yakıtta hem de dizelbiyogaz yakıtında eksik yanmadan kaynaklı enerji ve ekserji verimlerinde azalmalar meydana gelmektedir.

3. Yapılan ekserji analizinde yanma, tersinmezliklerin arasında en yüksek tersinmezlik kaynağı olarak bulunmuştur. Ayrıca, çift yakıtlı modda önemli ölçüde egzoz gazlarından kaynaklı ekserji kayıpları tespit edilmiştir. Bu egzoz kaybını engellemek için püskürtme zamanlaması ve sıkıştırma oranları gibi motor çalışma parametrelerin optimizasyonu araştırılmalıdır.

4. Çift yakıtlı modda düşük yükleme oranlarında tam yanmanın sağlamamasının nedeni biyogaz içerisindeki $\mathrm{CO}_{2}$ oranına yüksek olmasıdır. $\mathrm{Bu}$ oranın düşürülmesi veya $\mathrm{H}_{2}$ gibi kalorifik değeri daha yüksek ilave gazların kullanılması motor performansını olumlu katkı yapıp yapmadığ araştırılmalıdır.

Yüksek yükleme oranlarında çift yakıtlı modda biyogaz, enerji ve ekserji veriminde aşırı bir düşüş olmadan ve herhangi bir büyük motor modifikasyonu yapmadan alternatif bir biyo yakıt kaynağı olarak kullanılabilir. Bununla birlikte, çift yakıtlı sistemde düşük yüklerde biyogazdan daha iyi performans elde etmek için, çalışma parametrelerinde önemli değişiklikler gerektiği sonucuna ulaşılmıştır.

\section{Teşekkür}

Yazar bu çalışmayı gerçekleştirebilmesi için laboratuvar imkânlarını kullanmasına izin veren kıymetli hocalarına; Prof. Dr. Sebahattin Ünalan, Prof. Dr. Nafiz Kahraman ve Prof. Dr. Selahaddin Orhan Akansu'ya teşekkürlerini sunar.

\section{Kaynakça}

Atelge, M. R., Atabani, A. E., Abut, S., Kaya, M., Eskicioglu, C., Semaan, G., ve ark. (2021). Anaerobic co-digestion of oil-extracted spent coffee grounds with various wastes: Experimental and kinetic modeling studies. Bioresource Technology, 322, 124470.

Atelge, M. R., Krisa, D., Kumar, G., Eskicioglu, C., Nguyen, D. D., Chang, S. W., ve ark. (2020). Biogas Production from Organic Waste: Recent Progress and Perspectives. Waste and Biomass Valorization, 11(3), 1019-1040.
Atelge, R. (2021). Türkiye'de Sı̆̆ır Gübresinden Biyoyakıt Olarak Biyogaz Üretiminin Potansiyeli ve 2030 ve 2053 Yillarında Karbon Emisyonlarının Azaltılmasına Öngörülen Etkisi. International Journal of Innovative Engineering Applications, 5(1), 56-64.

Bari, S. (1996). Effect of carbon dioxide on the performance of biogas/diesel duel-fuel engine. Renewable Energy, 9(1), 1007-1010.

Barik, D., Kumar, A., ve Murugan, S. (2018). Effect of Compression Ratio on Combustion Performance and Emission Characteristic of a Direct Injection Diesel Engine Fueled with Upgraded Biogas-Karanja Methyl Ester-Diethyl Ether Port Injection. Energy \& Fuels, 32(4), 5081-5089.

Barik, D., ve Murugan, S. (2014). Investigation on combustion performance and emission characteristics of a DI (direct injection) diesel engine fueled with biogas-diesel in dual fuel mode. Energy, 72, 760-771.

Barik, D., ve Murugan, S. (2016). Experimental investigation on the behavior of a DI diesel engine fueled with raw biogas-diesel dual fuel at different injection timing. Journal of the Energy Institute, 89(3), 373-388.

Bora Bhaskor, J., ve Saha Ujjwal, K. (2016). Theoretical Performance Limits of a Biogas-Diesel Powered Dual Fuel Diesel Engine for Different Combinations of Compression Ratio and Injection Timing. Journal of Energy Engineering, 142(2), E4015001.

Bora, B. J., ve Saha, U. K. (2016). Experimental evaluation of a rice bran biodiesel - biogas run dual fuel diesel engine at varying compression ratios. Renewable Energy, 87, 782-790.

Bora, B. J., Saha, U. K., Chatterjee, S., ve Veer, V. (2014). Effect of compression ratio on performance, combustion and emission characteristics of a dual fuel diesel engine run on raw biogas. Energy Conversion and Management, 87, 1000-1009.

Börjesson, P., ve Mattiasson, B. (2008). Biogas as a resourceefficient vehicle fuel. Trends in Biotechnology, 26(1), 713.

Çakmak, A., ve Bilgin, A. (2017). Exergy and energy analysis with economic aspects of a diesel engine running on biodiesel-diesel fuel blends. International Journal of Exergy, 24(2-4), 151-172.

Cheenkachorn, K., Poompipatpong, C., ve Ho, C. G. (2013). Performance and emissions of a heavy-duty diesel engine fuelled with diesel and LNG (liquid natural gas). Energy, 53, 52-57.

Duc, P. M., ve Wattanavichien, K. (2007). Study on biogas premixed charge diesel dual fuelled engine. Energy Conversion and Management, 48(8), 2286-2308.

Goga, G., Chauhan, B. S., Mahla, S. K., Dhir, A., ve Cho, H. M. (2020). Effect of varying biogas mass flow rate on performance and emission characteristics of a diesel engine fuelled with blends of n-butanol and diesel. Journal of Thermal Analysis and Calorimetry, 140(6), 2817-2830.

Henham, A., ve Makkar, M. K. (1998). Combustion of simulated biogas in a dual-fuel diesel engine. Energy Conversion and Management, 39(16), 2001-2009.

Huang, J., ve Crookes, R. J. (1998). Assessment of simulated biogas as a fuel for the spark ignition engine. Fuel, 77(15), 1793-1801. 
Jadhao, J. S., ve Thombare, D. G. (2013). Review on exhaust gas heat recovery for IC engine. International Journal of Engineering and Innovative Technology (IJEIT) Volume, 2.

Karaağaç, M. O., Kabul, A., ve Oğul, H. (2019). First-and second-law thermodynamic analyses of a combined natural gas cycle power plant: Sankey and Grossman diagrams. Turkish Journal of Physics, 43(1), 93-108.

Karim, G. A. (2010). Combustion in Gas-fueled Compression Ignition Engines of the Dual Fuel Type Handbook of Combustion (pp. 213-235).

Kiliç, B., ve Osman, İ. (2019). Thermodynamic Analysis of The Organic Rankine Cycle Using Diesel Engine Waste Heat Recovery. Avrupa Bilim ve Teknoloji Dergisi(15), 112-117.

Kumar Sharma, P., Sharma, D., Lal Soni, S., Jhalani, A., Singh, D., ve Sharma, S. (2020). Energy, exergy, and emission analysis of a hydroxyl fueled compression ignition engine under dual fuel mode. Fuel, 265, 116923.

Luijten, C. C. M., ve Kerkhof, E. (2011). Jatropha oil and biogas in a dual fuel CI engine for rural electrification. Energy Conversion and Management, 52(2), 1426-1438.

Matuszewska, A., Owczuk, M., Zamojska-Jaroszewicz, A., Jakubiak-Lasocka, J., Lasocki, J., ve Orliński, P. (2016). Evaluation of the biological methane potential of various feedstock for the production of biogas to supply agricultural tractors. Energy Conversion and Management, 125, 309-319.

Mohamed Ibrahim, M., Varuna Narasimhan, J., ve Ramesh, A. (2015). Comparison of the predominantly premixed charge compression ignition and the dual fuel modes of operation with biogas and diesel as fuels. Energy, 89, 990-1000.

Mustafi, N. N., Raine, R. R., ve Verhelst, S. (2013). Combustion and emissions characteristics of a dual fuel engine operated on alternative gaseous fuels. Fuel, 109, 669678.

Sorathia, H. S., ve Yadav, H. J. (2012). Energy analyses to a ciengine using diesel and bio-gas dual fuel-a review study. world, 1(5).

Subramanian, K. A., Mathad, V. C., Vijay, V. K., ve Subbarao, P. M. V. (2013). Comparative evaluation of emission and fuel economy of an automotive spark ignition vehicle fuelled with methane enriched biogas and CNG using chassis dynamometer. Applied Energy, 105, 17-29.

Tippayawong, N., Promwungkwa, A., ve Rerkkriangkrai, P. (2007). Long-term operation of a small biogas/diesel dual-fuel engine for on-farm electricity generation. Biosystems Engineering, 98(1), 26-32.

Verma, S., Das, L. M., ve Kaushik, S. C. (2017). Effects of varying composition of biogas on performance and emission characteristics of compression ignition engine using exergy analysis. Energy Conversion and Management, 138, 346-359.

Verma, S., Das, L. M., Kaushik, S. C., ve Bhatti, S. S. (2019a). The effects of compression ratio and EGR on the performance and emission characteristics of dieselbiogas dual fuel engine. Applied Thermal Engineering, 150, 1090-1103.

Verma, S., Das, L. M., Kaushik, S. C., ve Tyagi, S. K. (2018). An experimental investigation of exergetic performance and emission characteristics of hydrogen supplemented biogas-diesel dual fuel engine. International Journal of Hydrogen Energy, 43(4), 2452-2468.

Verma, S., Das, L. M., Kaushik, S. C., ve Tyagi, S. K. (2019b). An Experimental Comparison of Enriched Biogas and CNG on Dual Fuel Operation of a Diesel Engine. IOP Conference Series: Earth and Environmental Science, $264,012004$.

Verma, S., Kumar, K., Das, L. M., ve Kaushik, S. C. (2020). Effect of Hydrogen Enrichment Strategy on Performance and Emission Features of BiodieselBiogas Dual Fuel Engine Using Simulation and Experimental Analyses. Journal of Energy Resources Technology, 143(9).

Yildiz, İ. b., ve Çalişkan, H. (2020). Motor Yüküne Bağli Olarak Bİyodİzel Yakitli Bİr Dİzel Motorun Enerjİ Ve Ekserjí Analİzİ Sonuçlarinin Değerlendİrİlmesİ. Mühendislik Bilimleri ve Tasarım Dergisi, 8(3), 833-843. 